Received: 13.03.2013; Final Text: 12.05.2014

Keywords: Ankara; retail geography; organised food retailers; political economy.

\section{EMPIRICAL ANALYSIS OF THE SPATIAL DISTRIBUTION OF ORGANISED FOOD RETAILERS IN ANKARA WITH REGARD TO NEIGHBOURHOODS' SOCIAL, ECONOMIC AND PHYSICAL CHARACTERISTICS}

\author{
A. Burak BÜYÜKCIVELEK*
}

\footnotetext{
* Department of City and Regional Planning, Faculty of Architecture, METU, Ankara, TURKEY.
}

\section{INTRODUCTION}

Commercial activities are considered to be a very important part of urbanisation process due to both its economic role and its importance in the social reproduction inhabitants. Today, with the increasing specialisation in economic activities and sophistication of daily lives the peculiar role of retailing solidified more and consequently the number of retail based studies have increased to a considerable degree in recent years. Based on this view, the paper aims to develop a research path with special emphasis on retailing's contribution on social and economic structure of cities.

In defining the aim as above, retail activities are seen as an inseparable part of general urbanisation process and it is hypothesised that retail activities tend to follow already established social and economic variations, sometimes lessen but mostly aggravating them. The trend necessitates political economic explanations that encompass both the formation of social and economic differentiations and urbanisation process in a comprehensive way. To this end various retail theories are analysed in relation with their social and economic structure of cities and a new approach is proposed on the basis of the case of Ankara.

The paper initiates with the brief summary and critique of theories that consider production of retail environments as a part of general urbanisation process and explain the retail development in relation with urban dynamics. To this end, some theories that consider retailing individually in a rather isolated way, were not taken into account (Annex 1). The first part starts with ecological theories and continues with normative spatial theories that include both central place theories and spatial interaction models. The section is terminating with postmodern approaches. The second part of the paper is devoted to the case of organised food retailers (OFRs) in Ankara. This part aims to prove the relationship between socioeconomic characteristics of the neighbourhoods and OFR presence. In the third and final part the Ankara case is analysed with reference to literature 
about disadvantaged consumers and food-deserts, and proposals for further researches are developed.

\section{THEORETICAL APPROACHES TO UNDERSTAND RETAIL DEVELOPMENT PROCESS}

\section{Ecological Theories:}

Ecology is defined as the study of the relationship of organisms or group of organisms to their environment and ecological method is used by geographers, biologists and sociologists (Dawson, 1980, 118). Those ecological theories which try to understand the urban environment and the process of urbanisation date back to the establishment of the Chicago School (early 1920's). Park was the leading figure of the Chicago School and other members adapted the "Social Darwinist" ideas of Park in to their own spatial analyses. By employing "Social Darwinism", Chicago School theorists consider urban dynamics as natural processes. In their conceptualisation, all urban functions are considered to be in competition for limited places. Those functions which are more powerful than others dominate the most desired environments. During this natural process, some functions tend to get together to share positive externalities created by others and each other. They benefit from symbiosis or mutual dependence created by other functions.

Urban ecologists accept some biological notions like 'negotiation' with the environment, and search for an 'environmental balance'. These notions assume that there is a search for equilibrium between the environment and organisms; between the city and its functions. The severe competition for suitable land (or limited resources in general) is analysed from this starting point. Unlike the concepts and assumptions borrowed from biological ecology, urban ecologists also use certain biological processes to 'explain' spatial dynamics. Concepts like 'centralisation', the grouping of activities, people or institutions around a pivotal point; 'decentralisation', the movement of activities, people or institutions out of a pivotal point (like suburbanisation); 'nucleation', the spatial clustering of economic and other activities; 'segregation', the isolation of certain group of people and activities from the main population or activity pattern; and 'invasionsuccession', the replacement of some activities or people with others; most of these were used to describe dynamics involved in urban processes (Reissman, 1964, 99-101).

Among the School members, it was Burgess (1925) who first developed a comprehensive theory of urban structure. It was known as concentric zone theory. In this theory Burgess considered population as the driving factor of changes in the city. A year after Burgess, Haig (1926) developed his theory of axial (or radial) development (1926). He considered land rents and transportation costs (frictional costs) as principal factors affecting urban development.

In 1933, Hoyt developed his sector theory (1933) where he argued different economic activities agglomerate (to benefit from mutual dependence) within unevenly shaped sectors. Another conceptualisation, known as multiple nuclei theory was introduced by Harris and Ullman in 1945. In their proposition, the idea of an ordered urban internal structure was replaced by an urban pattern made up of nested functions. In the theory it is suggested that similar functions which have similar spatial needs tend to cluster in specialised districts and form mini-centres inside larger 
zones. Mann observing British cities developed his sector-zone theory in 1965. In his theory, Mann combined the concentric structure of the Burgess conceptualisation with the suburban developments of multiple nuclei theory. Different from others, it was first Mann who discovered some relationship between negative externalities of urban development and social structure of the city (Flanagan, 1993).

According to Gottdiener et al. (2000, 110), while European thinkers such as Weber, Marx and Simmel viewed urban environment as a consequence of larger forces of capitalism, Chicago School theorists preferred biologybased conceptualisations and analogies to explain urban life. High level of abstraction and strict attachment to biological analogies not only lead to the general ignorance of intra sectorial dynamics but also cause to the misreading of the mechanisms contributing to the urbanisation process and retail development by ignoring social and economic relationships (Harvey, 1973, 131-2). Although land economics enters into explanations economic competition only considered as a special case within the broader process of struggle for survival by Chicago School theorists.

\section{Central Place Theory (CPT)}

Central place theory (CPT) has always been one of the most extensively used theories in the field of economic geography and planning. As classically developed by Christaller in 1933, the theory aims to describe and analyse the size, number and distribution of towns as service centres. Apart from accepting the assumptions of neo-classical economics, central place theory assumes that:

- A threshold of demand exists below which a good cannot be economically offered for sale. So, in order to support each good a minimum population is required.

- The size of population (or trade area) thus depends on the type of good.

- Centres are hierarchically classified according to type of good offered at the centre or according to the size of trade area.

- Higher ranked centres also contain the goods offered by lower order centres.

- Free entry of business produces a contraction of trade areas.

The basis of Christaller's representation is that utilisation of highest order goods derive a set of locations and hexagonal market areas covering the territory (which is assumed to be a plain). Berry argues that the realisation of such a pattern requires a long-run optimum which provides the maximum number of stores with minimum size of market areas (Berry, 1967, 64). After the establishment of the market areas for higher order goods, services providing lower order goods take their places according to geometrical principles meeting the maximum distance from the higher centres without leaving empty spaces in the geography. The pattern based on hexagons develops under this logic. This geometrical formation is considered to be the result of rational consumer behaviour that requires the evaluation of alternatives and selection of cheapest alternatives.

Lösch looked at the central place theory from a different perspective and contributed to its development a few decades after Christaller. Unlike Christaller, Lösch departed from locating lowest order goods and derived a triangular-hexagonal arrangement of centres and market areas. The 
resulting landscape becomes a hexagon divided by six 60 degree sectors radiating from the centre. Comparing these two models, Berry concludes that Christaller's formulation appears especially relevant for understanding the geography of retail and service business while Lösch's formulation is better for explaining the spatial distribution of market-oriented manufacturing (Berry, 1967, 73).

Despite their accuracy in explaining regional distribution of services, $\mathrm{CPTs}$ are thought to be limited in contributing to our understanding of intra-urban activity patterns. The static nature of the models limits considerably their development and explanation capacity. Although some recent attempts aim to break this rigidity through the utilisation of qualitative methods (like questionnaire surveys in Dennis et al., 2002) and development of newer concepts (like consumption threshold in Daniels, 2007), central place theories cannot be linked to the urbanisation process as much. Their ignorance of broader social and economic conditions and reduction of social and economic dynamisms into social and economic equilibrium models can be mentioned as the principal factors causing to the failure of the models. Especially when economics are concerned, it is hardly possible to find a moment of equilibrium (Harvey, 1973, 175) and these models can only represent ideal, hypothetical conditions with few real life input.

\section{Spatial Interaction Models (SIMs)}

Spatial interaction models (SIMs) are distinct from other location theories being mathematical developments to calculate the commercial attraction of two activities with respect to visiting populations and the distance between them. The concept of spatial interaction was first adapted from Newton's gravity model to the field of spatial science by Reilly in 1931. Since then it has been subjected to many modifications as a marketing and planning tool. SIMs, in their most basic form, assume that the trade relationship between two spaces (cities, areas, or shopping centres) is considered to be in direct proportion with populations they have (cover, serve, or attract) and in inverse proportion with the square of the distance between them. This simple analogue model further matured through the entry of multiple centres, probabilistic calculus related to centres and consumers, differentiated population groups and other measures of attraction like floorspace and turnover.

Recent developments in computer technologies together with the availability of data on urbanisation and retail development processes are observed under the complexity theory. This field of study not only offers new insights to researchers but also combines CPT with SIMs. According to Batty (2007) the departing point of complexity theory is that the city is a very complex and dynamic process, and instead of top-down regulating principles one needs to start understanding the city from the bottom, from the micro organisations making the city. So, these "'self-organising systems' construct the city which is a self-organising system as well. Complexity theorists, as did CPT and SIM theorists, investigate the rules guiding this organisation and try to find out the guiding patterns within each organisation and thus become able to predict the future of the system. Utilisation of populations, store numbers, distances and relative attractivity indexes produces non Euclidian geometries which are non-linear and multi scalar in character (Batty, 2007, 58). Urban entities' dynamic and dependent nature analysed through fractals, models of cellular automata and agent based models. 
Figure 1. Simulation of Cincinnati (left) and actual land use (simplified), 1960 (right); (White, 1998, 117).

Figure 2. Connections between the nodes of the urban web: (a) over-concentration creates a singularity and exceeds the channel's carrying capacity; (b) the same number of nodes better distributed. (Salingaros, 1998, 57).
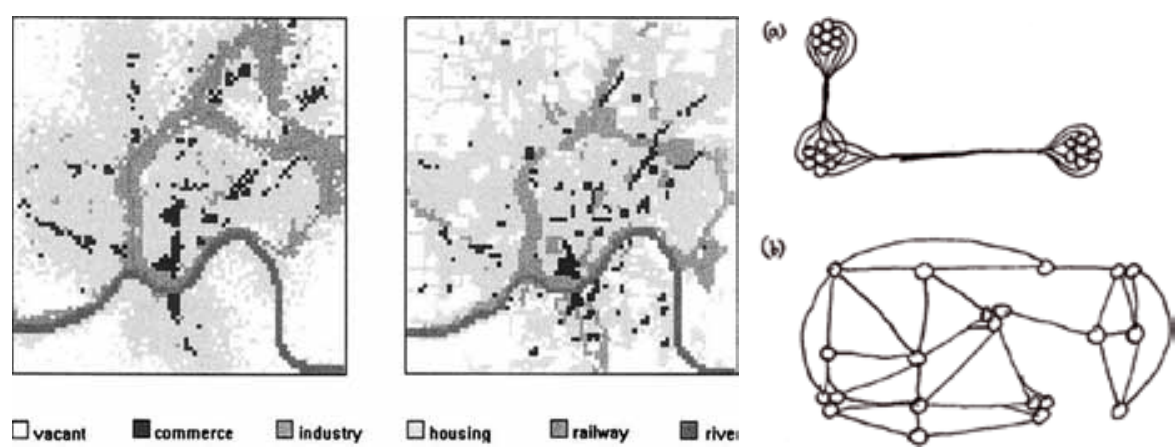

Tannier and Pumain (2005) focusing more on the utilisation of fractals for the analysis of the evolution of urban systems, distribution of activities, at different scales indicate that the fractals have the ability to simulate urbanisation dynamics as they produce "alternate patterns of continuity and fragmentation at the same time" (Tannier and Pumain, 2005, 2). Similar to CPTs fractal structures are also characterised by the repetition of the same distribution principle of elements at a multitude of scales and develop on the basis of principles like changes in the land prices and accessibility (Tannier and Pumain, 2005, 6). Referring to the utilisation of fractals in practice, in the field of planning, Tannier and Pumain (2005) suggest that fractals (like other self-organisation models) can be used to solve optimisation problems related to the accessibility of different populations to central activities. In an earlier research again departed from the complexity theory, Salingaros (1998) develops his theory of 'urban web' based on rules derived from connectivity principles, pattern recognition and artificial intelligence. Nodes, connections and hierarchy are the basic components of Salingaros' urban web idea. He argues that;

"We come to a crucial observation from complex systems: hierarchical organization requires that components of different sizes fit properly into the whole. The pieces of the urban web are simple, and they interact in a simple manner; yet their union is highly complex" (Salingaros, 1998, 68).

On the side of SIMs, Jensen-Butler (1972) claims that although interaction models attempted to be related to social physics and economic principles (like utility maximisation) they failed to have a theoretical basis. He also adds that spatial interaction models reflect the interests of the firm although they have the potential to be utilised to enhance consumption practices on the supply side. Based on this same criticism, Coelho and Wilson (1976) claim that SIMs should be accepted as 'allocational' in nature rather than 'locational' as they aim first at the allocation of firms at the most advantageous locations. Another stream of critics focused on models' static character. Because SIMs are based on parameters obtained from existing situations they become dysfunctional in the face of changing conditions. Their inadaptability to changing conditions makes them vulnerable in medium and long term estimations. Based on these criticisms, it is possible to claim that spatial interaction models could offer neither a comprehensive analysis tool nor bring explanation to urban processes.

When complex systems theories are considered their departure point was the limitations of the SIMs. Despite the utilisation of complicated techniques (like fractal geometries or cellular automata simulations) SIMs produce other kind of rigidities as a result of the rather static nature of the models which can never replace the complexity of the real life. These 
models aim to predict the future of the existing conditions based on some initial assumptions, but rapid and unexpected changes in actual conditions (especially when retailing is considered) cannot be represented in the models. To illustrate, although regional shopping malls and local retail businesses are in close relationship, complex systems approaches hardly encompass both cases in one model.

\section{Postmodern Approaches}

Dear and Flusty $(1998,50)$, referring to postmodern thinkers Derrida and Mills, argue that we are now living in a world whose social, economic, cultural and political conditions are totally different from what is called a 'modern age'. Considering these changes, they conclude that our conceptualisation of the city should change accordingly. Postmodern approaches suggest that it is time to quit traditional, rational and deterministic explanations of urban structure which can be traced to "factorial ecologies of intra-urban structure, land-rent models, studies on urban economies and diseconomies of scale, and designs for ideal cities and neighbourhoods" (Dear and Flusty, 1998, 51), and establish a new (postmodern) urbanism based on centreless urban form shaped by global-local links, social polarisation and re-territorialisation. Based on these thoughts, authors developed a number of concepts to identify basic characteristics of the postmodern city.

Firstly, a dense network of telecommunication and transportation enables the city to use global information for the benefit of localities with high efficiency. Secondly, the dominant mode of production for the city is post-Fordist and based on flexibility. Thirdly, although the city is composed of different cultural groups, a new urban culture based on consumption characterises its inhabitants (commodified communities). As the role of capitalist structures increases in favour of big business, the gap between rich and poor will widen much more than ever and create a bipolar society. In terms of the physical appearance of the city, eclectic architecture is considered to be the dominant architectural form. Within the conceptualisation of a postmodern city, it is assumed to be governed by 'polyanarchy' which is described as a pathological form of anarchy. The system is also thought to be disempowering to those who would challenge the controlling beneficiaries of the new world of "bipolar disorder" (Dear and Flusty, 1998, 64).

In relation to the distribution of intra-urban retail activity, the concept of postmodern urbanism provides two abstract concepts, "Flexism" and "Keno Capitalism" that could lead to the emergence of abstract conclusions. "Flexism" is described as: "a pattern of 'econo-cultural' production and consumption characterised by near-instantaneous delivery and rapid redirectability of resource flows" (Dear and Flusty, 1998, 61). Under "flexism", globally floating abstract ideas can easily be grounded and concretised with the help of an advanced infrastructure network. Additionally, what was once concretised may soon be abstracted and float away in search of another locality. The volatile character of capital and commodities is due to global forces which have superiority over local ones. All investment and disinvestment decisions are taken at the global level and global decisions shape the social, cultural and economic landscapes of localities.

'Keno capitalism' is the second term used by Dear and Flusty (1998) to describe the locational logic of land-uses at the urban level. On the basis 
Figure 3. Keno Capitalism, a locational model for postmodern urban structure. (Dear and Flusty,1998).

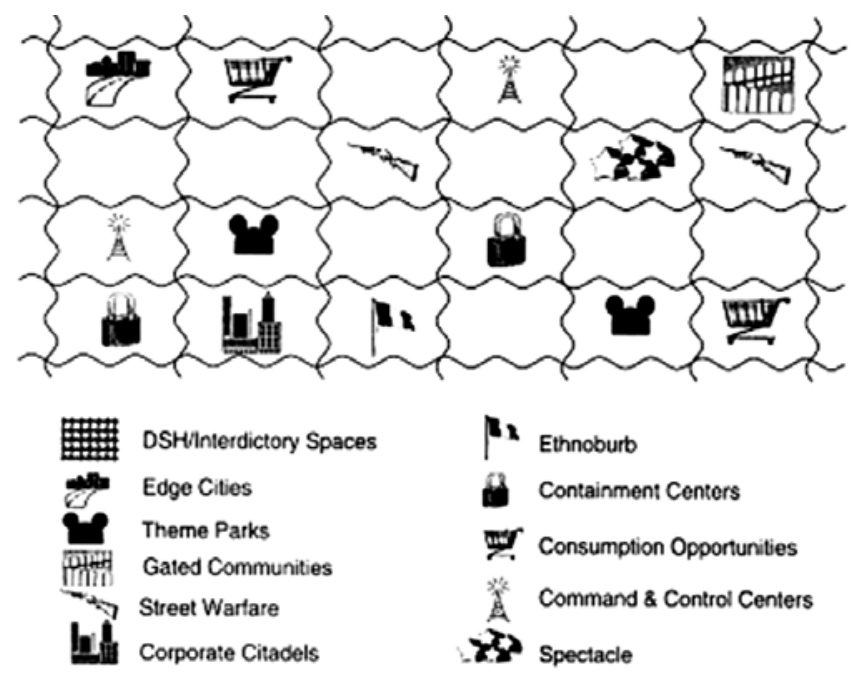

of advanced telecommunication and transportation technologies, it is argued that the comparative advantage of places within urban areas has disappeared. Homogenisation of people and cities at the global level has solidified with the homogenisation of urban landscapes. Firms (or functions) taking locational decisions, do not need to take into account different features of localities as each locality has become a featureless landscape. Furthermore, as firms are globally connected, the importance of agglomeration economies or economies of scale has disappeared and firms become independent of other land uses. Authors describe the process as follows: "In the absence of conventional communication and transportation imperatives mandating propinquity, the once-standard Chicago School logic has given way to a seemingly haphazard juxtaposition of land uses scattered over the landscape" (Dear and Flusty, 1998, 62). As a result, location decision of land uses is accepted as a very random and indefinable procedure that is hard to comprehend with the help of existing concepts and knowledge.

The city is conceptualised as an absolute grid made up of "disinformation super highway" which enables the unhindered and instantaneous flow of commodities and information. Within this grid, land uses set down randomly and form random patterns of land uses. The process causing this formation identifies which city will attain a successful pattern of land uses which brings wealth, although cities have no chances to affect these processes. As the development of one parcel has no influence on others, the outcome would be a "non-contiguous collage of parcelled, consumption oriented landscapes" (Dear and Flusty, 1998, 63-6).

There are numerous criticisms directed towards this new conceptualisation of urban space under postmodernism. Sui (1999) points out that ideas posed by Dear and Flusty are generally contradictory, problematic, and based on dubious and mostly unnecessary assumptions. Furthermore, he claims that instead of bringing any clarification, arguments on postmodern urbanism create ambiguities on our understanding of cities. Later in his article, Sui questions the general literature on postmodern urban geography and criticises the dependency on social factors.

"Most of the postmodernists' writings are largely wrong (although sometimes for the right reasons); most frequently, we cannot even tell 
whether they are right or wrong since we are told that everything is socially constructed" (Sui, 1999, 409).

The reductionist aspect of the theory, considering space and distances, is another point of criticism. Despite technological advances in information and telecommunication systems and its positive effect on a globalised network, at the local level goods, information and humans are carried through transportation networks. The conceptualisation of cities without the effect of transportation requires further assumptions putting additional obstacles for linking the theory with reality.

In relation to the above mentioned criticism, the assumption related to the parcellation of urban land into undifferentiated grids creates another contrasting point between theory and reality. Even if all other factors (such as the equal provision of infrastructures) are provided equally to each plot, due to differential advantages of accessibility one would soon differentiate from each other and would start to accommodate differential populations and activities. In a city which is divided up into different land use and population profiles, it is not possible to talk about undifferentiated plots. Established social and cultural patterns, together with flourishing land uses, will differentiate some plots from others and affect the location of investments. From the users' point of view, to accept the undifferentiated plots assumption we need to further assume that adjacent land uses have neither positive nor negative effects. Such secondary assumptions together with primary ones move us further away from reality and force us to turn back on an absolute understanding of space although the intention of postmodern school is the reverse.

The assumption related to domination of specific urban conditions by the imperatives of postmodern culture is also open to criticism. Although it is possible to talk about structural changes affecting the social, economic and cultural life of cities which are connected via global networks, different physical, historical and cultural backgrounds cause deviations in the development of different cities. Furthermore, as mentioned by Harvey (1973), different social groups have different capacities for internalising such transformations. From this perspective, it would be accurate to accept such transformations as processes rather than specific moments in time and instead of showing the Los Angeles city as a model, it would be better to accept differential urban dynamics transforming each city in a more-or-less different way.

\section{SOCIO-ECONOMIC FACTORS AND RETAIL DEVELOPMENT PROCESS}

\section{The case of Ankara}

The city of Ankara, with a population of 4,6 million people, is the second largest city in Turkey after İstanbul. With the establishment of the Republic, Ankara was selected capital and became seat for governmental functions. Economically, despite its low industrial profile, Ankara contributes to the development of technology and production of high value industrial products, with its highly qualified universities, and with their successful technology development zones. Despite this, the city is mostly dependent on service sector functions which both cover governmental functions, and personal and business services.

With compare to other large cities, in terms of social structure, Ankara can be considered as the least cosmopolitan. High level government 
officers and small amount of wealthy capitalist classes represent the higher sections of Ankara's population structure. The densest middle level is at one side characterised by ordinary government officers, university staff and students. On the other side of the composition there exist middle class service sector workers. At the bottom level of the social structure, lower class service workers and small number of industrial workers are positioned. The lines between broadly defined social classes are also visible in differentiated consumption patterns and life styles.

Ankara has the second largest economy in the country and produces 9\% of all GNP. It is generally believed that Ankara's economic structure, that is mainly dependent on service sector, makes the city strong against economic crises as most wages do not directly affected by the negativities of economic crisis. This, economic wise, makes the city relatively stable despite few investment opportunities when compared with more industrialised towns like İstanbul, İzmir and Kocaeli. Despite limitations, Ankara's established economic structure makes the city attractive especially for housing and retail investments while former benefits from long term loan options (like mortgage) and the latter enjoys middle profile but stable purchasing potential of consumers.

Despite its low financial and industrial profile, Ankara has a very developed commercial structure based on its service sector leading economy. In the year 2008, Ankara occupies respectively the fifth and third positions in the list of Turkish cities contributing to the national exports and imports (Hürriyet Ekonomi, 2009). Under this powerful macro-economic trends and very dynamic urban re-structuration process, Ankara's retail sector has been rapidly transforming since mid-1990s. In 2008, with $800.000 \mathrm{~m}^{2}$ of gross leasable retail area (GLA), Ankara comes just after İstanbul (Pamir and Soyuer, 2008). But when urban populations are taken into account with reference to the year 2011, Ankara occupies the first place with $246 \mathrm{~m}^{2}$ of GLA per 1000 person (AYD, 2012).

While the transformation of the retail sector of Ankara gradually modernises the city's retail profile, it also causes to the slow but steady decline of the traditional retail structure of Ankara. On the side of non-food retailing shopping centre developments and increasing number of chain stores are establishing pressures over traditional, capital-weak, individual retailers (Aksel-Gürün, 2009). On the side of food retailing, the sector has been transforming in favour of organised formats and at the expense of traditional convenience stores. As pointed out by different researches (Mc Kinsey and Co., 2003; Price Waterhouse Coopers, 2007), although the number and market share of traditional food retailers (convenience stores, street bazaars, kiosks, etc.) still dominates the food retail market when the number of stores and market shares are considered, it is underlined that the trend will soon be changed in favour of organised formats.

\section{Presentation of the data}

To analyse the relationship between retail location preference and socioeconomic characteristics two different data sources are utilised.

On the side of organised food retailers, the research is focused on 18 major organised food retail companies having 516 stores functioning in metropolitan area (1) of Ankara (2). As a consequence of the geographical 
3. See Annexe 4.

Figure 4. Populations of the neighbourhoods and distribution of the organised food retailers in Ankara. Drawn by the author based on TUIK (2008).
Figure 5. Neighbourhoods' population densities based on the populations of the year 2008 and distribution of organised food retailers in Ankara. Drawn by the author based on TUIK (2008). retailers. The address information about store locations is obtained through firms' internet web pages which reflect up-to-date information about the location of their stores for the year 2007. The stores are then assigned to neighbourhoods and positioned on the GIS map of Ankara on the basis of their addresses.

Neighbourhoods are differentiated on the basis of their social, economic and physical characteristics. To realise this different sources are utilised (3). Turkish Statistical institute (TUIK) provides most of the data. General Census of Population of the year 2008 provides most of the social and

economic indicators at the neighbourhood detail. General Census of

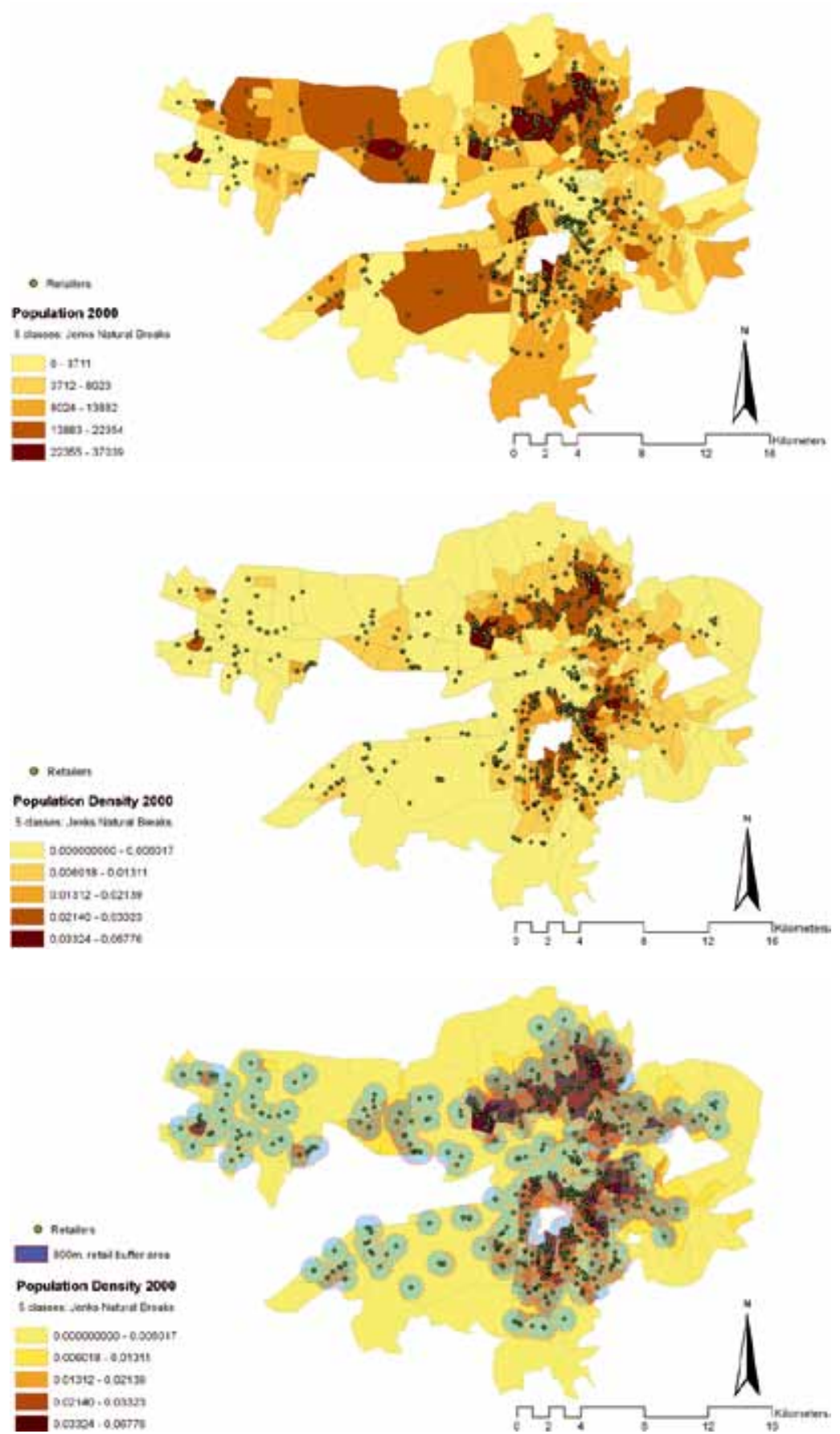
year 2000 and distribution of organised food retailers with 800 meter retail buffer radius. Drawn by the author based on TUIK (2008). 
4. See Annex 5 for explanation on the limitations of the research; see Annexe 6 for further explanation on retail presence in neighbourhoods and for the authors' adaptation of the concept of inequality to the present research.
Building of the year 2000 offers information about physical condition of buildings again at the same neighbourhood scale. Average square meter land prices of the year 2006 are obtained from the web site of the Revenues Administration. The street level data aggregated to neighbourhoods based on obtained averages. Finally the digitised neighbourhood map of metropolitan Ankara is obtained from the Middle East Technical University, Faculty of Architecture Maps and Documentation archive (4).

\section{Analysis of the Present Situation}

Population distribution and population densities

Considering the locational preference of organised food retailers the most important thing to be considered is the population that create the demand. Figure 4 shows the population distribution among neighbourhoods and Figure 5 provides information about population densities in addition to point distribution of OFRs. On the basis of the Figure 6, it is possible to observe that near central parts of the city, retailers tend to follow population densities. Moving to the outer skirts of the city (towards North-West and South-West), it is seen that although densities decreases in some neighbourhoods, retail presence still persists. Despite these specific conditions, reflecting socio-economic peculiarities, for the majority of other neighbourhoods located around the periphery of Ankara the decline of the population density is followed by decreasing number or non-presence of OFRs.

Based on this initial investigation, it is possible to conclude that there exist some factors other than population and population densities that contribute to the spatial distribution of OFRs when the case of metropolitan Ankara is considered. For this respect, the analysis is developed further to include social, economic and physical characteristics of neighbourhoods to test these indicators' relationship with OFR presence.

Formation of neighbourhood groups and their spatial analysis

At this stage of the analysis the present situation of the geographical distribution of organised food retailers (OFR) in Ankara is examined on the basis of neighbourhood characteristics. Primarily, neighbourhoods are grouped according to retail number they have within their borders. The groups are formed according to the maximum number of 11 organised food retailers and the minimum number of 0 organised food retailers. The first and most advantaged group of neighbourhoods is formed out of 6 neighbourhoods having 9 to 11 OFRs. The second group is composed of 16 neighbourhoods having 6 to 8 OFRs while the third group has 28 neighbourhoods having 4 to 5 OFRs. The fourth group of neighbourhoods each have 3 OFRs within their borders and in this group there exists 29 neighbourhoods. The fifth group is composed of 124 neighbourhoods having either 1 or 2 organised food retailers. The last and the least advantaged group of the study, the sixth group, is formed out of 135 neighbourhoods having no organised food retailer inside its borders.

After defining the neighbourhood groups in relation with OFR presence, the situation is first examined spatially. The relative location of advantageous and disadvantageous neighbourhoods is inspected with reference to general urban characteristics of Ankara. Secondly, the investigation is expanded with statistical comparisons. Percentages reflecting social, economic and physical characteristics of neighbourhoods are compared with Ankara's overall averages (indicated as percentages 
Table 1. Neighbourhood groups according to the number of organised food retailers functioning within neighbourhood area.

\begin{tabular}{|c|c|c|}
\hline $\begin{array}{l}\text { 1st group: neighbourhoods with } 9 \\
\text { to } 11 \text { organised food retailer }\end{array}$ & \multirow{6}{*}{$\leftrightarrow$} & \multirow{6}{*}{$\begin{array}{l}\text { Demographic indicators } \\
\text { Educational indicators } \\
\text { Economic indicators } \\
\text { Physical indicators }\end{array}$} \\
\hline $\begin{array}{l}\text { 2nd group: neighbourhoods with } \\
6 \text { to } 8 \text { organised food retailer }\end{array}$ & & \\
\hline $\begin{array}{l}\text { 3rd group: neighbourhoods with } 4 \\
\text { to } 5 \text { organised food retailer }\end{array}$ & & \\
\hline $\begin{array}{l}\text { 4th group: neighbourhoods with } 3 \\
\text { organised food retailer }\end{array}$ & & \\
\hline $\begin{array}{l}\text { 5th group: neighbourhoods with } 1 \\
\text { or } 2 \text { organised food retailer }\end{array}$ & & \\
\hline $\begin{array}{l}\text { 6th group: neighbourhoods with } 0 \\
\text { organised food retailer }\end{array}$ & & \\
\hline
\end{tabular}

of Grand Total), differentiated neighbourhoods from the general Ankara profile are identified and OFR presence in these neighbourhoods is analysed accordingly.

Spatial analysis of the OFR presence: When one investigates the geographical distribution of neighbourhood groups according to the organised food retail number they have it is hardly possible to explain the reasons of such distributions with reference to general knowledge about the city. At first sight, it is observed that neighbourhoods occupying some central locations and having some local peculiarities (being at the intersection of main roads, being located at main commercial corridors/ strips or being the neighbourhood centres) are obtaining much larger

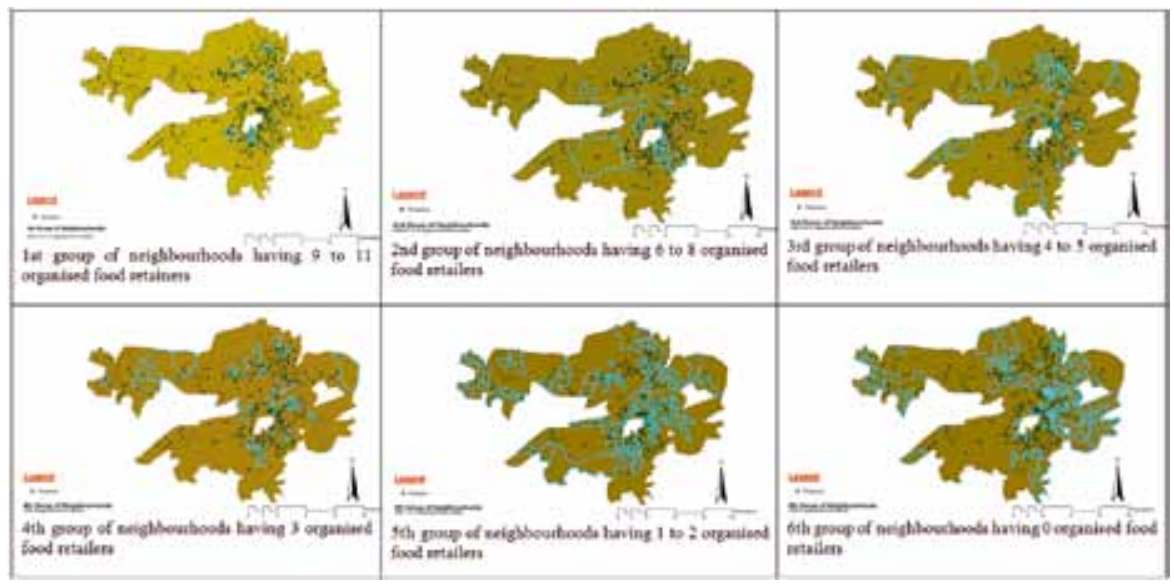

Fures 7-12. Maps indicating groups of neighbourhoods according to different number of organised food retailer.
Figure 13. Distribution of the neighbourhoods having 0 organised food retailers.

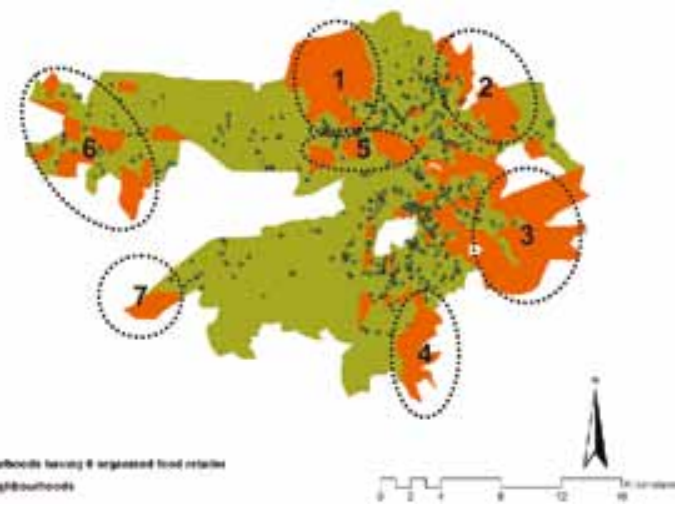


5. Neighbourhood names within the identified areas are as follows: 1 (Solfasol, Karakum, Yeşiltepe, Güzelyurt, etc.), 2 (Küçük Kayaş, Araplar, Yukarı İmrahor, etc.) and 3 (Yukarı Dikmen, Aşağı Dikmen, etc.). number of OFRs than others. At the other extreme, the least advantaged neighbourhoods are spotted around the areas of Mamak district (southeast), Keçiören district (East), northern parts of Yenimahalle district (central north-east) and at the periphery of Eryaman districts. The first three districts are known as the economically most disadvantaged districts of Ankara whereas Eryaman district is composed of residential areas for the military personnel in which development of any kind, including the retail development is strictly controlled.

Despite this very general knowledge about the relationship between district characteristics and organised food retail distribution, one needs to investigate in detail the reasons affecting this formation. For this reason in the following parts, beyond districts' economic characteristics, the socio economic structure of neighbourhoods is examined at various levels.

The first group of neighbourhoods, having no organised food retailer within their boundaries is composed of neighbourhoods having quite similar spatial profiles. These are mostly those neighbourhoods located at the periphery of traditional Ankara and through corridors they penetrate just at the edge of the traditional city centres, Ulus and Kizllay. This development pattern is very typical and associated with the formation of 'gecekondus'.

This development starts at the edge of the legally developed lands where the control of local government is weak and suitable land for development is available. Then with the legal and political support 'gecekondu' areas penetrate into the city through main transportation arteries. Areas marked with 1, 2, 3 and 4 (5) are the examples of this kind of development. Other than 'gecekondu' areas the area number 5 has a specific character. In addition to its residential population this area has some important uses which affect its character to a considerable degree. Industrial functions (İvedik Organised Industrial Zone) together with the largest cemetery of Ankara (Karşıyaka) are located in this area numbered 4. Area number 6 partially belongs to Sincan and partially belongs to the Etimesgut Municipalities. Despite that the area is developed on a legal basis, different from its surroundings, it is habited by people belong to lower socio economic profile. Area number 7 (Yaşamkent) has a different character than the rest as this is an upper class newly developing area. The only explanation that can be given to this part of land is that due to its novelty retailers have not taken position yet. But in the course of time, when this

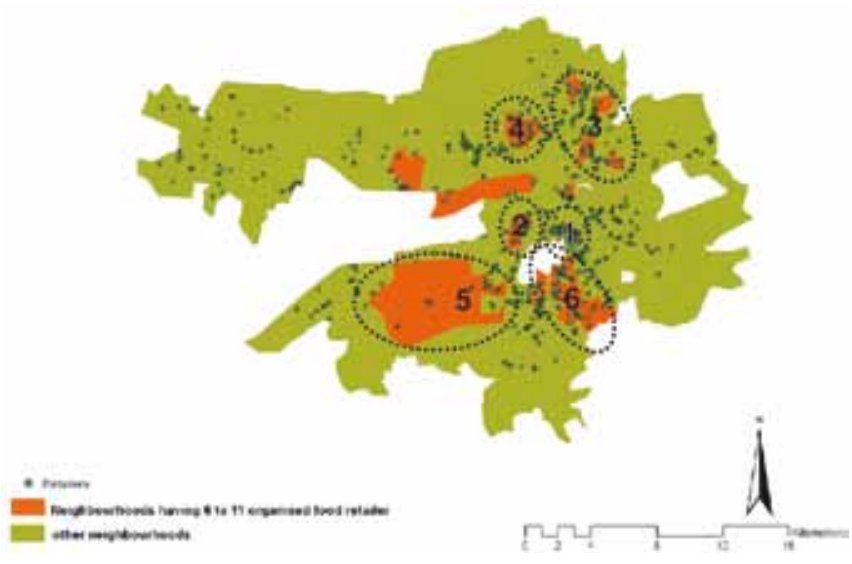


area is developed as areas nearby (like Çayyolu and Konutkent) it will not be surprise to observe good amount of retailers.

The second group of neighbourhoods are considered to be the most advantageous group as they are having the highest number of retailers among the three groups. Instead of occupying large areas in the city, this third group is made up of 'retail niches' which show central characteristics either at the city or more local level. Neighbourhood group number 1 is located at the centre of the traditional city centres Kizilay and Ulus. Number 2 is a very important sub-centre, Emek-Bahçelievler. Those neighbourhoods grouped around number 3 are the very local centres (Etlik, Kavacik-Subayevleri) serving to their vicinity. Number 4 is also local centre (Öveçler) serving also neighbourhoods located at the south of this neighbourhood. Number 5 is a very large neighbourhood having both residential and university areas inside. İşçi Blokları neighbourhood, the small area located just east of the large universities area, is not only serving to the residential area surrounding it but also serving to the east part of the universities area where Middle East Technical University is located. Among all neighbourhood groups one illustrates a different spatial pattern than others. The group number 6 indicates upper and middle class neighbourhood areas of Ayrancı, Çankaya and Birlik neighbourhoods.

The relationship between social indicators and OFR presence

Neighbourhood population and household size: When we look at the population distribution in accordance with the retail geography we see striking inequalities. The first and second group of neighbourhoods representing a bit more than $10 \%$ of Ankara's population contain more than $30 \%$ of the retailers while the most disadvantaged 6th group representing almost $70 \%$ of the population is unable to attract any retailer within their borders. After the general population distribution it is important to observe household size which is utilised as an important socio economic indicator in different researches. It is known that there is an indirect relation between household size and socio economic development as households are more aware of birth control mechanisms and unwillingly to have more children to be less sensible to economic fluctuations. According to TUIK (2008) Ankara has an average household size 3,82 people. This information helps to divide the household size range into two categories: households having 4 and less persons and households having 5 or more persons.

According to Table 2, 75\% of households in Ankara have a size lower than 5 persons. When one looks at the demographic character of the first four neighbourhood groups it is seen that households having less than 5 persons are over represented compared to general Ankara's profile. While the second group has 10\% smaller households than Ankara's average, 6 th group has $6 \%$ more larger households. 5th group represents a break line between smaller and larger household groups. From the point of view of retail distribution, it is interesting to see that $70 \%$ of food retailers are located at neighbourhoods (groups 1, 2, 3 and 4) where one third of households having less than 5 members are located.

Civic Status: Civic (marital) status can also be used as a good indicator of socio economic development. In contrast to modern social groups, in traditional societies marriage is considered as a natural event that one has to face with just after his or her maturation. For this reason it can be assumed that the age of marriage is relatively low and the ratio of marriage is relatively high in traditional parts of the societies when compared with 
Table 2. Analysis of population and

household sizes (4 and less persons, 5 and more persons) according to neighbourhood groups.
Table 3. Analysis of the civic status according to neighbourhood groups. the modern parts. Considering the part of Ankara's population older than 15 years old, there exists a significant relationship between civic status of the persons and retail distribution. Ankara, in general, has $62 \%$ of its population married. While the 6th neighbourhood group represents more than expected married persons in its borders, 5th group shows similar characteristics to the overall Ankara. Rest of the groups have much fewer married couples and especially the second group has 9\% less than Ankara's average. Regarding the relationship with the retail presence, one third of the total married people is living in the group of neighbourhood having no retailer, and almost $2 / 3$ of them has either one or no retail option in their neighbourhood. In contrast to this, married households in the first two groups of most advantaged neighbourhoods represent a bit more than one tenth of all married households and receiving service from almost one third of all retailers in their neighbourhood.

Level of education: Education level of persons affects their social and economic life to a considerable degree. From job finding to wage earning, people differ from each other according to their education background. For a long time Turkey have been applying the policy of compulsory

\begin{tabular}{|c|c|c|c|c|c|c|c|c|}
\hline & population 2008 & $\%$ & households 4 and less & $\%$ & households 5 and more & $\%$ & OFR number & $\%$ \\
\hline \multirow[t]{2}{*}{ neighbourhood group 1} & 150413 & 4 & 29053 & 4 & 8594 & 4 & 59 & 11 \\
\hline & & & 77 & & 23 & & & \\
\hline \multirow[t]{2}{*}{ neighbourhood group 2} & 251721 & 7 & 59914 & 8 & 10494 & 4 & 112 & 20 \\
\hline & & & 85 & & 15 & & & \\
\hline groups 1,2 & 402134 & 11 & 88967 & 12 & 19088 & 8 & 171 & 31 \\
\hline \multirow[t]{2}{*}{ neighbourhood group 3} & 449651 & 12 & 84706 & 11 & 23654 & 10 & 125 & 23 \\
\hline & & & 78 & & 22 & & & \\
\hline groups 1,2, 3 & 851785 & 23 & 173673 & 23 & 42742 & 18 & 296 & 54 \\
\hline \multirow[t]{2}{*}{ neighbourhood group 4} & 436106 & 12 & 72877 & 10 & 22272 & 9 & 93 & 17 \\
\hline & & & 77 & & 23 & & & \\
\hline groups $1,2,3,4$ & 1287891 & 35 & 246650 & 33 & 65014 & 27 & 389 & 70 \\
\hline \multirow[t]{2}{*}{ neighbourhood group 5} & 1366099 & 37 & 247423 & 33 & 81568 & 34 & 164 & 30 \\
\hline & & & 75 & & 25 & & & \\
\hline groups $1,2,3,4,5$ & 2652990 & 71 & 493973 & 67 & 146582 & 60 & 553 & 100 \\
\hline \multirow[t]{2}{*}{ neighbourhood group 6} & 1066853 & 29 & 209617 & 28 & 93054 & 38 & 0 & 0 \\
\hline & & & 69 & & 31 & & & \\
\hline \multirow[t]{2}{*}{ grand total } & 3720843 & 100 & 742291 & 100 & 243306 & 100 & 553 & 100 \\
\hline & & & 75 & & 25 & & & \\
\hline
\end{tabular}

more than grand total \% same as grand total \% less than grand total \%

\begin{tabular}{|c|c|c|c|c|c|c|c|c|c|c|}
\hline & divorced & ever maried & widow & total unmarried & $\%$ & married & $\%$ & total & OFR number & $\%$ \\
\hline \multirow[t]{2}{*}{ neighbourhood group 1} & 1947 & 36718 & 4599 & 43264 & 4 & 66030 & 4 & 109294 & 59 & 11 \\
\hline & & & & 40 & & 60 & & & & \\
\hline \multirow[t]{2}{*}{ neighbourhood group 2} & 5442 & 81851 & 10972 & 98265 & 9 & 113035 & 7 & 211300 & 112 & 20 \\
\hline & & & & 47 & & 53 & & & & \\
\hline groups 1,2 & 7389 & 118569 & 15571 & 141529 & 13 & 179065 & 11 & 320594 & 171 & 31 \\
\hline \multirow[t]{2}{*}{ neighbourhood group 3} & 6165 & 109802 & 14082 & 130049 & 12 & 194806 & 11 & 324855 & 125 & 23 \\
\hline & & & & 40 & & 60 & & & & \\
\hline groups $1,2,3$ & 13554 & 228371 & 29653 & 271578 & 26 & 373871 & 22 & 645449 & 296 & 54 \\
\hline \multirow[t]{2}{*}{ neighbourhood group 4} & 5185 & 89472 & 12864 & 107521 & 10 & 169001 & 10 & 276522 & 93 & 17 \\
\hline & & & & 39 & & 61 & & & & \\
\hline groups 1,2,3,4 & 18739 & 317843 & 42517 & 379099 & 36 & 542872 & 32 & 921971 & 389 & 70 \\
\hline \multirow[t]{2}{*}{ neighbourhood group 5} & 16003 & 312521 & 39678 & 368202 & 35 & 589940 & 35 & 958142 & 164 & 30 \\
\hline & & & & 38 & & 62 & & & & \\
\hline groups $1,2,3,4,5$ & 34742 & 630364 & 82195 & 747301 & 71 & 1132812 & 67 & 1880113 & 553 & 100 \\
\hline \multirow[t]{2}{*}{ neighbourhood group 6} & 10963 & 272337 & 32550 & 315850 & 30 & 565712 & 33 & 881562 & 0 & 0 \\
\hline & & & & 36 & & 64 & & & & \\
\hline \multirow[t]{2}{*}{ grand total } & 45139 & 893893 & 113292 & 1052324 & 100 & 1697193 & 100 & 2749517 & 553 & 100 \\
\hline & 2 & 33 & 4 & 38 & & 62 & & 100 & & \\
\hline \multicolumn{11}{|l|}{ more than grand total \% } \\
\hline \multicolumn{11}{|l|}{ same as grand total \% } \\
\hline less than grand total \% & & & & & & & & & & \\
\hline
\end{tabular}


Table 4. Analysis of the education level according to neighbourhood groups.

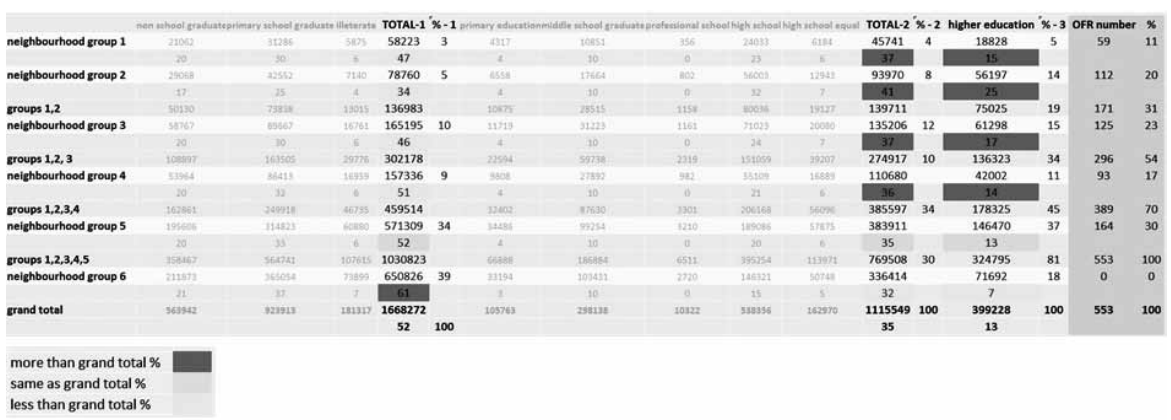

education during primary school for five years. Recently the period of compulsory education increased to 9 years to cover middle school as well. To this end the education profile of Ankara is divided into three categories. The first one covers non school graduates, illiterates and 5 years primary school graduates. The second group is consisting middle school graduates to high school graduates. The final cluster indicates the graduates from higher education institutions. For Ankara which is the second largest city in Turkey and which has a relatively well established education hierarchy, the significance of the first group stayed at very low level whereas neighbourhoods started to differentiate when percentages of high school and higher education graduates are considered. As happened in previous indicators, the first four groups of neighbourhoods have more of high school and higher education graduates than Ankara's averages. While the second group has significantly higher concentrations than the rest $(12 \%$ more than average), the sixth group includes the lowest graduate level of all groups (6\% less than average). If the first four groups can be considered advantageous in terms of education, the presence of retailers accentuates this advantage as they include $70 \%$ per cent of all considered retailers. $7 \%$ of all higher education graduates are living in the most disadvantaged sixth group and could not receive service from any organised food retailer within their neighbourhoods.

The relationship between economic indicators and OFR presence

Position in the job market and population not in the labour force: Position in the job market indicates whether individuals are integrated with the economy or not. According to TUIK statistics, $44 \%$ of Ankara's population is economically active and $86 \%$ of this is employed. Although the employed population in second and third group is 1 to $2 \%$ higher than Ankara's average, neighbourhood groups do not differ from each other substantially. Unemployed population is also evenly distributed among neighbourhood groups. Considering the position in the job market, small differences occurred between first neighbourhood groups and the last ones and the differences did not exceed $2 \%$ variation. But when one observes the composition of the population out of labour force interesting differences appear. First three groups of neighbourhoods which are benefiting more from the existing retail distribution include more student and retired populations than Ankara's population whereas fifth and sixth group of neighbourhoods have relatively higher percentage of housewife with compare to other groups and Ankara's averages. Strikingly high percentage of students ( $9 \%$ higher than Ankara's average) and low percentage of housewives (12\% lower than Ankara's average) highlight once more the second group of neighbourhoods. Within the population not in the labour force while students are considered as potentially active members of the 
Table 5. Analysis of the position in the job market according to neighbourhood groups.

Table 6. Analysis of the population not in the labour force according to neighbourhood groups.
Table 7. Analysis of the economic activity classes according to neighbourhood groups.

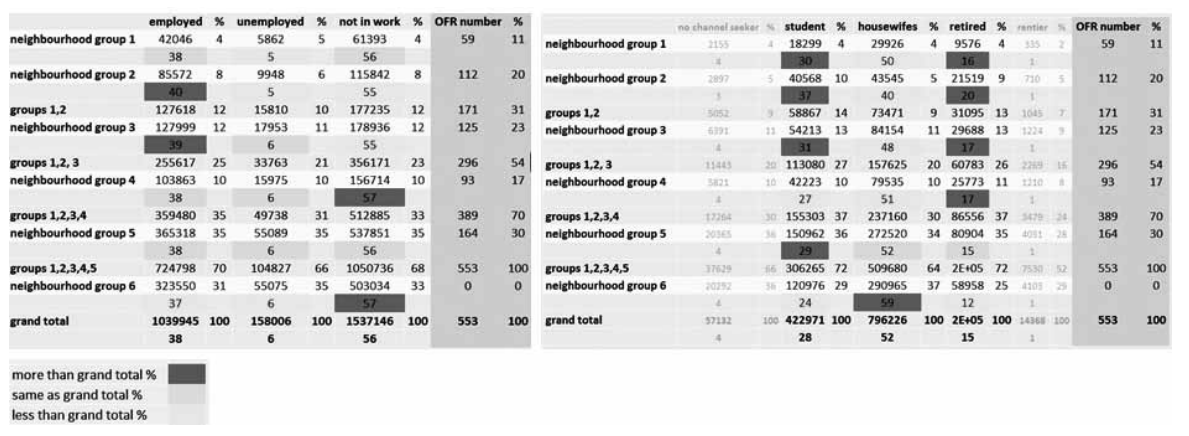

\begin{tabular}{|c|c|c|c|c|c|c|c|c|c|c|c|c|c|c|c|c|}
\hline & manuf & $\%$ & elec_eas_wat & 96 & constr & $\%$ & trade & $\%$ & transp_str & $\%$ & FIRE & $\%$ & services & $\%$ & OFR number & $\%$ \\
\hline \multirow{2}{*}{ neighbourhood group 1} & 4999 & 3 & 487 & 4 & 2463 & 3 & 7925 & 7 & 2884 & 4 & 5871 & 5 & 16936 & 4 & 59 & 11 \\
\hline & 12 & & 1 & & 6 & & 19 & & 7 & & 14 & & 41 & & & \\
\hline \multirow[t]{2}{*}{ neighbourhood group 2} & 7243 & 5 & 1032 & 9 & 4555 & 6 & 12346 & 7 & 3855 & 6 & 13385 & 11 & 42115 & 10 & 112 & 20 \\
\hline & 9 & & 1 & & 5 & & 15 & & 5 & & 16 & & 50 & & & \\
\hline groups 1,2 & 12242 & 8 & 1519 & 13 & 7018 & 9 & 20271 & 11 & 6739 & 10 & 19256 & 16 & 59051 & 14 & 171 & 31 \\
\hline \multirow[t]{2}{*}{ neighbourhood group 3} & 14195 & 9 & 1376 & 12 & 8726 & 11 & 21562 & 12 & 7590 & 12 & 16547 & 14 & 53624 & 12 & 125 & 23 \\
\hline & 11 & & 1 & & 7 & & 17 & & 6 & & 13 & & 43 & & & \\
\hline groups $1,2,3$ & 26437 & 17 & 2895 & 25 & 15744 & 21 & 41833 & 23 & 14329 & 22 & 35803 & 30 & 112675 & 26 & 296 & 54 \\
\hline \multirow[t]{2}{*}{ neighbourhood group 4} & 13572 & 9 & 1127 & 10 & 6539 & 9 & 19143 & 11 & 6906 & 11 & 13131 & 11 & 44683 & 10 & 93 & 17 \\
\hline & 13 & & 1 & & 6 & & 18 & & 7 & & 12 & & 43 & & & \\
\hline groups $1,2,3,4$ & 40009 & 26 & 4022 & 35 & 22283 & 29 & 60976 & 34 & 21235 & 33 & 48934 & 40 & 157358 & 37 & 389 & 70 \\
\hline \multirow[t]{2}{*}{ neighbourhood group 5} & 54830 & 36 & 4192 & 36 & 25780 & 34 & 61201 & 34 & 22406 & 34 & 44130 & 36 & 147188 & 34 & 164 & 30 \\
\hline & 15 & & 1 & & 7 & & 17 & & 6 & & 12 & & 41 & & & \\
\hline groups $1,2,3,4,5$ & 94839 & 62 & 8214 & 71 & 48063 & 63 & 122177 & 69 & 43641 & 67 & 93064 & 77 & 304546 & 71 & 553 & 100 \\
\hline \multirow[t]{2}{*}{ neighbourhood group 6} & 57585 & 38 & 3394 & 29 & 27872 & 37 & 56035 & 31 & 21527 & 33 & 28227 & 23 & 125399 & 29 & 0 & 0 \\
\hline & 18 & & 1 & & 9 & & 18 & & 7 & & 9 & & 39 & & & \\
\hline \multirow[t]{2}{*}{ grand total } & 152424 & 100 & 11608 & 100 & 75935 & 100 & 178212 & 100 & 65168 & 100 & 121291 & 100 & 429945 & 100 & 553 & 100 \\
\hline & 15 & & 1 & & 7 & & 17 & & 6 & & 12 & & 42 & & & \\
\hline \multicolumn{17}{|l|}{$\begin{array}{l}\text { more than grand total \% } \\
\text { same as grand total \% }\end{array}$} \\
\hline $\begin{array}{l}\text { same as grand total \% } \\
\text { less than grand total \% }\end{array}$ & & & & & & & & & & & & & & & & \\
\hline
\end{tabular}

near future, retired people are seen as sources of economic and social stability. Increased number of housewives not participating in the labour force cannot be considered just as a cultural factor. The situation has to be seen as a sign of economic and social disintegration or non-integration in the context of advanced capitalist economy.

Economic activity: The economic activity that individuals are working has always been considered as a very important indicator of socio economic status. Economic activities in Ankara can majorly be classified under four sectors, three of which have significant spatial implications. As mentioned before, the service sector in Ankara, with a percentage of $42 \%$ is the most powerful economic activity. Services are followed by trade sector which occupies $17 \%$ of all employments. Despite their economic importance these two sectors are considered as weak indicators as their distribution among neighbourhood groups do not reflect any significant correlation with the distribution of organised food retailers. Similarly, the members of the construction sector and those working in gas, electricity and water services and labourers in the sector of transportation and storage are taken out of considerations due to their low number and random distribution among neighbourhood groups. Despite the development and diversification of the economy and despite its service based character the socio economic difference between white and blue collar workers is still an efficient indicator, at least for the case of Ankara.

With $15 \%$ manufacturing and with $12 \%$ finance, insurance and real estate services (FIRE) come after services and trade. Different from other sectors, manufacturing and FIRE are made up of relatively well defined, homogeneous group of people, and can be utilised as good indicators of socio-economic differentiation. When the characteristics of 
Table 8. Analysis of the occupation classes according to neighbourhood groups.

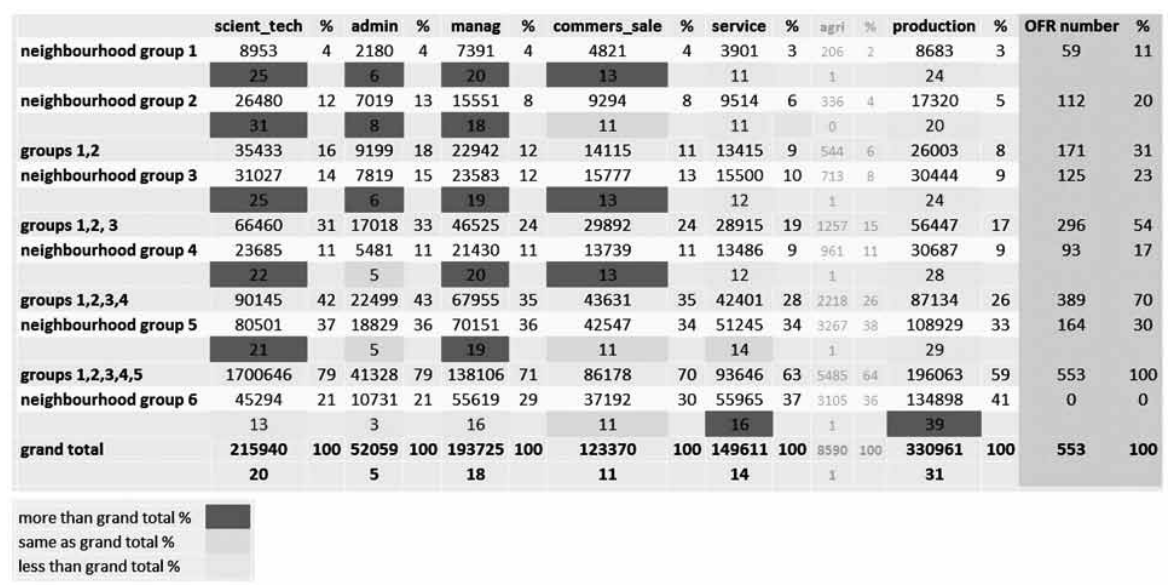

the neighbourhood groups are compared with these sectors, it is found that in neighbourhood groups where the presence of manufacturing workers is higher than Ankara's average, the presence of FIRE workers is lower. The first two groups of neighbourhoods having almost one third of organised food retailers also have $16 \%$ of all FIRE workers. FIRE workers are accompanied with upper classes of trade (for the $1^{\text {st }}$ group) and service sector (for the second group) workers. The lowest two neighbourhood group, receiving service from at most two organised food retailer is differentiated from other groups majorly through the workers in the manufacturing sector and then by the workers in the construction activity and lower classes of trade workers.

Occupation: The occupation of people working in an economic sector can be different from the characteristic of the economic activity. The descriptions (upper and lower classes of trade and service activities) used to underline divisions within economic sectors can be concretised and verified through variations in occupation. According to statistics, first four groups of neighbourhoods share the same characteristic of having scientific and technical personnel, managerial workers and administrators at higher percentages than the Ankara averages. At the other end of the scale, the sixth and the fifth groups are characterised with the higher percentages

\begin{tabular}{|c|c|c|c|c|c|c|c|c|c|c|}
\hline & reg_casu_empl & $\%$ & employer & $\%$ & self_emp & $\%$ & unp_fam_wor & $\%$ & OFR number & $\%$ \\
\hline \multirow[t]{2}{*}{ neighbourhood group 1} & 33862 & 4 & 2964 & 6 & 4117 & 5 & 1076 & 5 & 59 & 11 \\
\hline & 81 & & 7 & & 10 & & 3 & & & \\
\hline \multirow[t]{2}{*}{ neighbourhood group 2} & 71805 & 8 & 6298 & 12 & 5910 & 7 & 1453 & 6 & 112 & 20 \\
\hline & 84 & & 7 & & 7 & & 2 & & & \\
\hline groups 1,2 & 105667 & 12 & 9262 & 17 & 10027 & 12 & 2529 & 11 & 171 & 31 \\
\hline \multirow[t]{2}{*}{ neighbourhood group 3} & 103777 & 12 & 8071 & 15 & 10308 & 12 & 2739 & 12 & 125 & 23 \\
\hline & 83 & & 6 & & 8 & & 2 & & & \\
\hline groups $1,2,3$ & 209444 & 23 & 17333 & 33 & 20335 & 24 & 5268 & 23 & 296 & 54 \\
\hline \multirow[t]{2}{*}{ neighbourhood group 4} & 91455 & 10 & 5819 & 11 & 9613 & 12 & 2640 & 12 & 93 & 17 \\
\hline & 83 & & 5 & & 9 & & 2 & & & \\
\hline groups $1,2,3,4$ & 300899 & 34 & 23152 & 44 & 29948 & 36 & 7908 & 35 & 389 & 70 \\
\hline \multirow[t]{2}{*}{ neighbourhood group 5} & 311043 & 35 & 18411 & 35 & 27956 & 34 & 7739 & 34 & 164 & 30 \\
\hline & 85 & & 5 & & 8 & & 2 & & & \\
\hline groups $1,2,3,4,5$ & 611942 & 69 & 41563 & 78 & 57904 & 70 & 15647 & 69 & 553 & 100 \\
\hline \multirow[t]{2}{*}{ neighbourhood group 6} & 279829 & 31 & 11483 & 22 & 25140 & 30 & 7020 & 31 & 0 & 0 \\
\hline & 87 & & 4 & & 8 & & 2 & & & \\
\hline \multirow[t]{2}{*}{ grand total } & 891771 & 100 & 53046 & 100 & 83044 & 100 & 22667 & 100 & 553 & 100 \\
\hline & 85 & & 5 & & 8 & & 2 & & & \\
\hline \multicolumn{11}{|l|}{ more than grand total \% } \\
\hline \multirow{2}{*}{\multicolumn{11}{|c|}{ same as grand total \% }} \\
\hline & & & & & & & & & & \\
\hline
\end{tabular}


The relationship between physical indicators and OFR presence

Existence of basic amenities: General Census of Buildings for the year of 2000 provides various information that can be utilised for the determination of social and economic character of the neighbourhoods. However, some indicators that are thought to be useful at first sight are eliminated after preliminary statistical verifications (Annexe 7).

For this research, the information about the availability of kitchen, bathroom, toilet and clean water system in the flats is analysed. As expected in one of the most developed cities in Turkey, the absences are very low. For this reason the unavailability of such amenities and their presence outside residential units are added to each other. At the end, it is observed that the existence of these basic amenities decrease when one moves from most advantaged neighbourhood groups to less advantaged ones when number or organised food retailers is considered. Furthermore, considering that Ankara's average is only 1\% lacking facilities, any variation below or above is to be counted as important although proportions variations are very little. In İstanbul where neighbourhoods are very heterogeneous in terms of physical qualities this statistic may be considered less important. But for the case of Ankara, neighbourhoods are made from much more homogeneous physical units and, as can be seen from the table, not only the percentages but also absolute number of the low quality buildings increase from advantageous groups to less advantageous ones when neighbourhoods are grouped according to OFR presence.

Average land prices: With reference to discussions realised at the construction of the theoretical framework the part devoted to formation and acquisition of rent played an important role. So the relationship between land prices, socio economic characteristics of the neighbourhoods and retail presence are thought to produce very interesting results. Only indicator that can be found at the city scale is average land prices obtained from Revenue Administration (2006).

When the relationships are investigated different from initial expectations it was not possible to find direct correlation between social, economic and physical indicators. Interestingly the most advantaged group has followed the least advantaged groups' average land prices and represent lowest averages than the one of Ankara. As observed from the analysis of other indicators, the second group having six to eight organised food retailers within their borders characterise those neighbourhoods having the highest average land prices two times more than Ankara's average. With little
Table 11. Analysis of the average land price variation according to neighbourhood groups.

\begin{tabular}{|c|c|c|c|}
\hline & average land price & retail number & $\%$ \\
\hline neighbourhood group 1 & 177,7 & 59 & 11 \\
\hline neighbourhood group 2 & 434,7 & 112 & 20 \\
\hline neighbourhood group 3 & 245 & 125 & 23 \\
\hline neighbourhood group 4 & 251,7 & 93 & 17 \\
\hline neighbourhood group 5 & 223,8 & 164 & 30 \\
\hline neighbourhood group 6 & 145,8 & 0 & 0 \\
\hline average land price (Ankara, 326 neighbourhoods) & 211,6 & & \\
\hline
\end{tabular}

per square meter, in Turkish Liras

more than grand total $\%$

same as grand total \%

less than grand total \% 
fluctuations the movement from upper to lower groups is resulting with decrease in average land prices.

To finalise this part of the analysis one needs to underline the importance of much local and specific factors in the determination of land prices and locational preferences of both households and food retailers. On the side of retailers, firms may select expensive locations that are unfavourable by other activities, if these locations show potential for the extraction of desired profit levels. Furthermore, in accordance to their organised structure, firms do not select their locations based on individual store profitability. For some parts of the city, just to keep the competition live with other retailers, firms may decide to keep functioning in expensive, unprofitable areas.

\section{FINAL DISCUSSIONS}

Based on a limitation of previous approaches aiming to conceptualise the process of urban retail development, the present research aimed to develop a socio-economic perspective to understand the relationship between retail development process and other dynamics urbanisation. Throughout the research, the tight connection between social, economic and physical characteristics of the neighbourhoods and the presence of organised food retailers the research reveals is intended to be proved. Identification of neighbourhood groups according to the number of OFR and comparisons of their characteristics with Ankara averages revealed that for each category retailers tend to locate more on advantageous neighbourhoods of each category while disadvantageous neighbourhoods receive considerably less retailers.

When one re-examines earlier theories under the light of the findings presented above, the partial invalidity of earlier approaches becomes much clearer. Findings indicate the fact that socio-economic and physical characteristics are part of the major determinants in shaping urban retail environments. When ecological theories are considered, it is observed that market mechanisms that structure socio-economic characteristics are reduced to natural factors. Consequently, social factors participating to the formation of observed structures (like inequalities) are mostly ignored with this belief in natural mechanisms. Further to this, ad-hoc deductions of ecological theorists do not give any inference to planning works as it becomes almost impossible to intervene into the functioning of the decribed "naturalist" system.

When CPTs are considered, first think that needs to be identified is that these theories are utilised mainly for the construction of regional models and are based on multitude of uses (rather than a single use like OFR). Furthermore, when food products are considered, the basic concept of "differential demand thresholds" becomes much less functional as demand for food is less variable when compared with other commodities. On the supply side, when OFRs are taken into account, their internal variations are not as significant as variations between different retail sectors and unlike CPT findings the spatial distribution of OFRs does not form any hierarchical order. But here it is important to underline the fact that although OFRs are not distributed hierarchically they do neither be distributed homogeneously. According to findings presented in this research, OFR distribution is skewed and following the pattern of varying social and economic characteristics of the neighbourhoods. 
When the relevance of SIMs in the empirical analysis of OFRs is investigated, one observes that unlike the powerful attraction of commercial centres, OFRs mainly create small areas of attraction just covering their vicinity due to their high number. Additionally, when OFRs attractivity for other land uses is investigated (although hard to deduce from findings), in relation with their high flexibility, it is possible to claim that OFRs are following other land uses (like housing or commercial centre developments) rather than being an attraction point for them. On the computational side of SIMs, parametric approaches, agent based interaction models and cellular automata approaches can hardly grasp the complexity of retail formation processes, as factors (like political economy, legislative system, etc.) contributing to process can hardly be quantified and modelled. Within the framework of this research, the author can only argue that socio-economic and physical characteristics of neighbourhoods are among the major determinants of the OFR formation processes and these characteristics are in constant relation with changing political economic factors.

Under the light of findings, the author would like to spare some final words to the spatial assumptions of post-modern approach to urban retail formation. Findings reveal that the postmodern space conceptualisation of indifferent grids is highly unrealistic as grids (neighbourhoods) differ at least on the basis of social and economic characteristics. Relationally, this differentiation constitutes the basis for other differentiations including the geographical distribution of other land-uses (like OFRs). On the basis of the differentiating influence of market forces over the city, further researches may reveal other differentiations as economic activities tend to follow the highest profits and can hardly be located homogeneously unless urban structure has an homogeneous socio-economic profile.

In final words, the author would like to underline the importance of considering retail development as part of general urbanisation process. Within this view, despite its peculiar conditions, the case of organised food retailers in Ankara illustrates an exemplar instance within the spatialisation of capitalistic practices as emphasised by various authors (Harvey, 1985a and 1985b; Brenner and Theodore, 2002; Peck and Tickell 2008[2002]; Peck et al, 2009; Peck and Theodore, 2012). The case of Ankara illustrates also that with the capitalist urbanisation process; existing social, economic and physical variations (that are created previously during the production processes, consumption activities, or elsewhere) within the urban population are reproduced and aggravated by the production of numerous layer of urban activity. In this view, construction of different housing options, privatised infrastructure provision, locational preference of private hospitals and schools, production of green areas and retail development process can all be seen part of a broader capitalistic mechanism that is motivated by the imperatives of profit maximisation, competition and monopolisation. In such a world, where the need for "revolutionary theories" is more obvious than ever, urban planners become obliged to take responsibility of defending more egalitarian production of urban land uses being retailing or housing for the creation of more liveable cities than we are experiencing today.

\section{ACKNOWLEDGEMENT:}

The author would like to thank to referees for their comments and critics that contributed to the development of this article. 
Table 12. List of organised food retailers in Ankara covered within the research (Shopping centres are not considered within the presented research as their characteristics structurally differ from the characteristics of organised food retailers).

\section{ANNEXES:}

\section{Annex 1}

Examples from some of the commonly used but excluded theories:

Economic theories, theory of the firm; behavioural approaches; studies of "cultural turn"; production, distribution and consumption studies; political aspects of retailing and urban injustices, disadvantaged consumer and food desert studies.

\section{Annex 2}

\begin{tabular}{|c|c|c|c|c|c|c|}
\hline & firm name & firm presence & total number of stores & stores covered & missing stores & percentage covered \\
\hline 1 & migros-tansas-sok & international & 68 & 68 & 0 & 100 \\
\hline 2 & kiler & national & 55 & 50 & 5 & 91 \\
\hline 3 & bim & national & 126 & 115 & 11 & 91 \\
\hline 4 & peynirci & local & 36 & 36 & 0 & 100 \\
\hline 5 & makromarket & national & 63 & 55 & 8 & 87 \\
\hline 6 & cagdas & regional & 34 & 32 & 2 & 94 \\
\hline 7 & yunus & regional & 24 & 24 & 0 & 100 \\
\hline 8 & altunbilekler & local & 32 & 32 & 0 & 100 \\
\hline 9 & akyurt & local & 24 & 24 & 0 & 100 \\
\hline 10 & carrefour & international & 12 & 12 & 0 & 100 \\
\hline 11 & metro group & international & 3 & 2 & 1 & 67 \\
\hline 12 & tesco-kipa & international & 1 & 1 & 0 & 100 \\
\hline 13 & soykan & regional & 34 & 33 & 1 & 97 \\
\hline 14 & gimsa & local & 10 & 10 & 0 & 100 \\
\hline 15 & celikler & local & 17 & 17 & 0 & 100 \\
\hline 16 & basgimpa & local & 19 & 19 & 0 & 100 \\
\hline 17 & sekerciler & local & 8 & 8 & 0 & 100 \\
\hline 18 & macit & local & 8 & 8 & 0 & 100 \\
\hline 19 & shopping centres & (not included) & 37 & 35 & 2 & 95 \\
\hline total & & & 611 & 581 & 30 & 95 \\
\hline
\end{tabular}

\section{Annex 3}

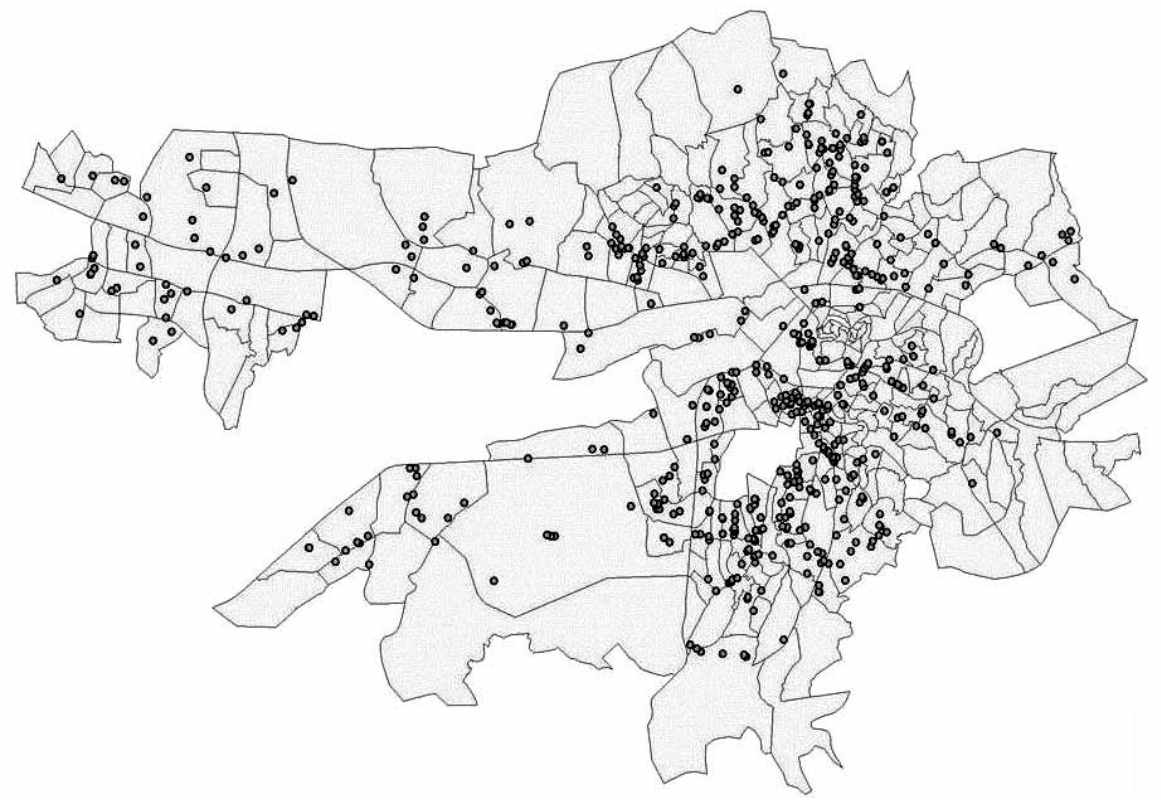

Figure 15. Point distribution of organised food retailers in the metropolitan area of Ankara with administrative neighbourhood divisions. 
Table 13. List of data resources utilised in the research (with publication dates, indicators and content).

\section{Annex 4}

\begin{tabular}{|c|c|c|c|}
\hline Source & Description of the data & indicator & content \\
\hline TUIK & General Census of Population & 2000 social, economic & $\begin{array}{l}\text { population, household information, civil status } \\
\text { education, economic activity, status in the job } \\
\text { occupation, employment }\end{array}$ \\
\hline TUIK & General Census of Buildings & 2000 physical & housing conditions \\
\hline TUIK & Household Consumption Survey & 2009 economic & $\begin{array}{l}\text { consumption pattern with reference to income } \\
\text { and expenditure quintiles }\end{array}$ \\
\hline TUIK & Address Based Population Registration System & 2008 social & women illiteracy ratio \\
\hline RA & Average Square meter Land Prices & 2006 economic & average land prices for neighbourhoods \\
\hline METU & Digital map of Ankara & 2007 physical & $\begin{array}{l}\text { neighbourhoods, roads and buildings } \\
\text { basemap and database system }\end{array}$ \\
\hline
\end{tabular}

TUIK: Turkish Statistical Institute

RA: Revenue Administration

METU: Middle East Technical University

\section{Annex 5}

Limitations of the Research

On the side of retailers, the research reflects the conditions of a specific picture in time and need to be modified according to changing aspects. Organised food retail companies covered in this research, their store numbers and their addresses are obtained during the summer of 2007 and the very dynamic retail geography of Ankara has already changed considerably until 2013. The research can only present the situation in 2007 and to investigate contemporary situation a new research needs to be conducted on the basis on up-to-date information.

OFRs covered in the research represent different retail capitals, functioning at different spatial scales. Furthermore, firms are all have their different development stories and different development strategies. Although these aspects did not taken into account within this research, all these dimensions could be considered as elements of a special research topic. But for the purpose of keeping track on spatial injustices, the author preferred not to consider differentiations among retailers and only took into account the retail presence in a neighbourhood as a necessary and enough condition of standardised food provision and accessibility.

Shopping centre development in Ankara also presents a very productive research ground in terms of consumption practices, store investment strategies and production of a newly emerging spatial monopolisation trends. But shopping centres are excluded from the research as their purpose cannot be limited with food retailing and more importantly because their attraction range exceeds neighbourhood level which is the unit of analysis of the research.

On the side of neighbourhood statistics there exist a mismatch between the dates of different sources. Based on the year 2007, author tried to gather the most up-dated information regarding the case. But, it is very hard to find neighbourhood level, comprehensive information in Turkey as most statistical data is obtained on the basis of urban level and detailed statistical investigations are realised on the basis of representative samples. For this, in order to bring together various data, the author utilised the most updated information for each group of indicator.

A final limitation comes from the theoretical choice of the author. The Marxist methodology followed during the research necessitated a class based analysis of neighbourhoods. But due to time limitations the author 
6. See Giddens (1973) on new class formations and Saunders $(1978,1984)$ on the formation of consumption and housing classes.

7. In this view, food products differ from other retail commodities both being a basic, physiological need, and having a frequent consumption and purchase pattern. These peculiarities increase the importance of accessibility to food products and necessitate its close availability to inhabited areas. preferred not to perform a discussion on new forms of class formation and its application on the case (6). At one side, based on preliminary knowledge about such a discussion and available data resources, the author believes that if would be impossible to find relevant data to construct the class geography of Ankara. On the other side, socio economic specialities, together with physical indicators are providing necessary information about neighbourhood differentiation and about neighbourhood's class characteristics.

\section{Annex 6}

Retail presence in neighbourhoods and inequality perspective of the research

The questions of inequality and injustices are very controversial. According to different political views these questions obtain different definitions. In Marxist point of view injustices constitutes the basis of social and economic structure. One group owns the means of production, controls the distribution and usage of limited sources, and exploits others labour to perform these actions. Another group occupies a contrasting position. This second group has no chance to obey to the former and earn wages to survive in the system. Social mobility among these groups (classes) can happen only momentarily while justice and equity can never be achieved as long as the capitalist system continues to define social and economic conditions.

Following this, the hypothesis is constructed on the belief that retailers (a sort of capitalist class, retail capitalists) have right to choose where to develop their business and free to quit the place whenever they desire. On the other side, there exist consumers belonging to different classes and according to their status they receive differential services from these retailers.

Within the framework of this research, in combination with Marxist approach and peculiarities of the organised food retail sector, the question of inequality is (re)defined as a factor of spatial accessibility. Inequality is assessed on the basis of the accessibility potential of inhabitants to food providers (7). In this view neighbourhoods are considered as the unit of analysis and retail presence within neighbourhoods is considered together with their socio economic characteristics. Guy $(2007,198)$ discussing the provision conditions in 'food deserts' in the UK develops the condition of 'inadequacy' as "a small shop selling little or no fruit and vegetables is not usually seen as an adequate outlet". Following this, the author accepts that the availability of one or more OFR satisfies the condition of accessibility; and the presence of more OFRs indicates to a better accessibility within the neighbourhood.

Neighbourhoods are assumed to be the nodes where daily retail practices are mostly satisfied within 800 meters maximum walking distance. However, size of neighbourhoods change considerably both in terms of population and in terms of surface. At the level of abstract statistics, the size of the neighbourhoods are normalised through the utilisation percentages while at the spatial level normalisation through surface area did not preferred for a number of reasons. Primarily most of the neighbourhoods, especially those located at the central areas have similar sizes. Secondarily, although some neighbourhoods have much larger areas then others their inhabited land is almost at the same size as other ordinary size neighbourhoods. 
As mentioned previously, despite differentiations in OFR characteristics, it is assumed that OFRs are able to provide more or less similar services based on food diversity, quality and price standard. As the research only aims to test the selective locational preference of organised food retailers with respect to neighbourhoods' socio economic characteristics, differential service provisions and unique consumption patterns did not taken into account.

Lastly, although the accessibility to one or more OFR satisfies the condition of equality or justice, the concepts are utilised just to evaluate defined relationship between OFRs and consumer characteristics. One should not consider this assumption as supremacy of modern formats over traditional ones, or as part of an urban retail vision that only includes modern retailers. In contrast, the research is performed to illustrate the selective nature of the modernisation trend in food retailing as an exemplary case that can be adapted to other profit based locational operations.

\section{Annex 7}

Eliminated building statistics

One of them is the building age. In conventional researches, the more recent the building is, it may indicate that its occupants are of higher echelons of the societies who are affording to live in newer flats. But in cities having much less newly developed land than already built up area, dynamics of housing market cannot overcome the locational conditions. In order not to sacrifice the advantageous locations they occupy, people in higher socio economic status prefer to live in older houses or apartment blocks. Newly constructed buildings can only attract middle class people who can afford to live in new places and having much less to loose while leaving their old place of residence.

Another important indicator might be the utilisation of natural gas. The utilisation of natural gas for heating started after 1988 and spread gradually. Independent of preferences of individuals, initial stages of the natural gas provision was realised according to the will and plans of local and central governments. Although today, households have the right to choose their heating system, established pattern of natural gas usage do not reflect this freedom of choice that came only lately. As a result this variable is not utilised in this research.

\section{BIBLIOGRAPHY}

AKSEL-GÜRÜN, B. (2009) Impact of Shopping Centers on the Fragmentation of the City Center, unpublished PhD thesis, City and Regional Planning Department, ODTÜ, Ankara.

Alışveriş Merkezi Yatırımcıları Derneği (AYD) (2012) Retail Sector in Turkey. [http://www.ayd.org.tr/TR/Data Bank.aspx] Accessed on 14.09.2013.

BATTY, M. (2007) Cities and Complexity: Understanding Cities with Cellular Automota, agent-based Models, and Fractals, University Press Group, London.

BERRY, B.J.L. (1967) Geography of Market Centers and Retail Distribution, New Jersey Englewood Cliffs. 
BRENNER, N., THEODORE, N. (2002) Cities and the Geographies of "Actually Existing Neoliberalism, Antipode, 34(3) 349-379.

BURGESS, E.W. (1925) The Growth of the City: An Introduction to a Research Project, The City eds. R.E. Park, E.W. Burgess and R.D. McKenzie, University of Chicago Press, Chicago; 47-62.

COELHO, J.D., WILSON, A.G. (1976) The Optimum Location and Size of Shopping Centres, Regional Studies (10) 413-21.

DANIELS, M.J. (2007) Central Place Theory and Sport Tourism Impacts, Annals of Tourism Research 34(2) 332-347.

DEAR, M., FLUSTY, S. (1998) Postmodern Urbanism, Annals of the Association of American Geographers 88(1) 50-72.

DENNIS, C., MARSHLAND, D., COCKETT, T. (2002) Central Place Practice: shopping centre attractiveness measures, hinterland boundaries and the UK retail hierarchy, Journal of Retailing and Consumer Services 9, 185-199.

FLANAGAN, W.G. (1993) Contemporary Urban Sociology, Cambridge University Press, Massacussets.

GIDDENS, A. (1973) The Class Structure of the Advanced Capitalist Societies, Hutchison University Library, London.

GOTTDIENER, M. (ed.). 2000. New Forms of Consumption: Consumers, Culture, and Commodification, Lanham, MA: Rowman and Littlefield.

GUY, C. (2007) Planning for Retail Development: A Critical View of the British Experience, Routledge, New York.

HAIG, R.M. (1926) Towards an Understanding of the Metropolis, Quarterly Journal of Economics (40) 402-34.

HARVEY, D. (1973) Social Justice and the City, Edward Arnold, London.

HARVEY, D. (1985a) Urbanisation of Capital: Studies in the History and Theory of Capitalist Urbanisation, Basil Blackwell, Oxford.

HARVEY, D. (1985b) The Geopolitics of Capitalism, Social Relations and Spatial Structures, ed. D. Gregory, J. Urry, Macmillan, London; 112131.

HOYT, H. (1933) One Hundred Years of Land Values in Chicago, University of Chicago Press, Chicago.

Hürriyet Ekonomi (2009) İşte rakamlarla Ankara. [http://hurarsiv.hurriyet. com.tr/goster/ShowNew.aspx?id=7666685] Accessed on 02.06.2013.

JENSEN-BUTLER, C. (1972) Gravity Models as Planning Tools, Geografiska Annaler 54(b) 68-78.

Mc Kinsey Global Institute (2003) Turkey: Making Productivity and Growth Breakthrough [http://www.mckinsey.com/insights/mgi/research/ productivity_competitiveness_and_growth/turkey_making_the_ productivity_and_growth_breakthrough] Accessed on 02.09.2010.

PAMIR AND SOYUER, DTZ (2008) Turkey Retail Market Overview. Retail Market Research. [http://balkans.com/relevant/b48a9-Turkey\%252 0Retail\%2520Market\%2520Overview\%25202008.pdf] Accessed on 14.03.2009. 
PECK, J., TICKELL A. (2008[2002]) Neoliberalising Space, Antipode, 34(3) 380-404.

PECK, J., THEODORE, N., BRENNER, N. (2009) Neoliberal Urbanism: Models, Moments, Mutations, SAIS Review (39/1) 49-66.

PECK, J., THEODORE, N. (2012) Reanimating Neoliberalism: Process Geographies of Neo-liberalisation, Social Anthropology 20(2) 117-185.

Price Waterhouse Coopers (2007) Transition of the Turkish Retail Sector and the impacts on the Economy, report prepared for the Turkish Council of Shopping Centres and Retailers (AMPD). [http://www.pwc.fr/assets/files/pdf/2008/04/pwc_transition_turkish_ retail_sector.pdf] Accessed on 16.05.2009.

REISSMAN, L. (1964) The Urban Process: Cities in Industrial Societies, Free Press, London.

Revenue Administration (2006) Minimum Square-meter Land Unit Values for Ankara [http://www.gib.gov.tr/index.php?id=827] Accessed on 14.06.2009.

SALINGAROS, N.A. (1998) Theory of the Urban Web, Journal of Urban Design, 3(1) 53-71.

WHITE, R. (1998) Cities and Cellular Automata, Discrete Dynamics in Nature and Society (2) 111-25.

SAUNDERS, P. (1984) Beyond Housing Classes: the Sociological Significance of Private Property Rights in Means of Consumption, International Journal of Urban and Regional Research 8(2) 202-227.

SAUNDERS, P. (1978) Domestic Property and Social Class, International Journal of Urban and Regional Research, 2(1-4) 233-51.

SUI, D., Z. (1999) Postmodern Urbanism Disrobed: or Why Postmodern Urbanism is a Dead End for Urban Geography, Urban Geography 20(5) 403-411.

TANNIER, C., PUMAIN, D. (2005) Fractals in Urban Geography: a Theoretical Outline and Empirical Example, Cybergeo: European Journal of Geography: Systemes, Modelisation, Geostatistiques. [http:// cybergeo.revues.org/3275; DOI : 10.4000/cybergeo.3275] Accessed on 23.05.2012.

Turkish Statistical Institute, TUIK (2008) Census of Population Social and Economic Characteristics of Population, TUIK Publications, Ankara. 
Alındı: 13.03.2013; Son Metin: 12.05.2014

Anahtar Sözcükler: Ankara; perakende coğrafyası; organize gıda perakendecileri; ekonomi politik.

\section{ANKARA KENTINDEKİ ÖRGÜTLÜ GIDA PERAKENDECILERININN; MAHALLELERINN TOPLUMSAL, EKONOMIK VE FIZİKSEL ÖZELLİKLERINNE GÖRE YER SEÇIMİ ÜZERİNE DENEYSEL BİR ÇÖZÜMLEME}

Kentleşme süreçleri ile perakende coğrafyasının dönüşümü arasındaki ilişki, 1900'lerin başından beri, kent planlama, coğrafya ve toplumbilim alanlarının ilgi odağı olmuştur. Geliştirilen farklı yaklaşımlar bu ilişkinin farklı boyutları üzerinde yoğunlaşmış, iki süreç arasındaki etkileşimin parçalarını nedensellikler üzerinden açıklamayı amaçlamıştır. Bu yazıda, Ankara kenti üzerine yapılan araştırma bulgularından yola çıkılarak geçmiş yaklaşımların parçacıl açıklamalardan öteye gitmediği, etkileşim sürecinin bütününü anlamaya ve bu bütüne müdahale etmeye yönelik açılımlar sağlamadığı savunulmaktadır. Kentleşme ve perakende coğrafyası arasındaki ilişkinin incelenmesindeki bu eksiklikten yola çıkan araştırma, kentsel gelişimin; kentlilerin toplumsal, ekonomik ve fiziksel özellikleri doğrultusunda şekillendiği savını Ankara kentindeki örgütlenmiş gıda perakendecilerinin mahalle özelliklerine göre dağılımı üzerinden doğrulamayı amaçlamıştır. Bu amaç doğrultusunda Ankara'da etkinlik gösteren 18 firmaya ait 516 örgütlü gida perakende noktası bulundukları mahallelerle ilişkilendirilmiş ve bulunma oranları ile mahallelerin toplumsal, ekonomik ve fiziksel özellikleri arasındaki ilişki incelenmiştir. Araştırma bulguları, örgütlü gıda perakende firmalarının mahallelerin toplumsal, ekonomik ve fiziksel özelliklerine göre yer seçmekte olduğunu göstermiştir. Bulgulara göre firmalar, üstünlükleri söz konusu olan mahallelerde daha çok sayıda bulunurken olumsuz konumdaki mahallelerde daha az varlık göstermektedirler. Sonuç olarak, kent-perakende gelişim ilişkisi üzerinde geliştirilecek yeni bir yaklaşımın ancak kentin toplumsal, ekonomik ve fiziksel özelliklerini etkileyen kentsel politik iktisadın gerçeklerini içererek bütüncül ve gerçeğe yakın bir modelleme sunacağ

\footnotetext{
AHMET BURAK BÜYÜKCIVELEK, B.CP., DEA Urbanism Received his B.CP in Urban and Regional Planning from Middle East Technical University (2000-2004). Earned his DEA (Diplôme d'Etudes Approfondies, French equivalent of Master's Degree) in Urbanism from Université Paris XII, Institut d'Urbanisme de Paris (2005). Currently, Research Assistant at METU, Department of City and Regional Planning and PhD candidate at University College London, Bartlett School of Planning. aburak@ucl.ac.uk, aburakb@metu.edu.tr
} 
